\title{
A rare cause of aspiration pneumonia
}

\author{
Anna Li, ${ }^{1}$ Lesley Bishop, ${ }^{2}$ Paula McParland ${ }^{2}$
}

${ }^{1}$ Department of Respiratory, Queen Alexandra Hospital, Portsmouth, UK

${ }^{2}$ Queen Alexandra Hospital, Portsmouth, UK

Correspondence to Dr Anna Li,

li.anna232@googlemail.com

Accepted 20 April 2015

\section{(a) CrossMark}

To cite: Li A, Bishop L, McParland P. BMJ Case Rep Published online: [please include Day Month Year] doi:10.1136/bcr-2015210423

\section{DESCRIPTION}

A previously fit and well 54-year-old woman presented with a subacute history of cough and white sputum production, with some associated lethargy and fatigue. She had no reflux or regurgitation symptoms. She was a smoker with a 20-pack year history. Spirometry showed a mild obstructive defect, suggesting chronic obstructive pulmonary disease. Chest X-ray showed patchy peripheral consolidative changes and she was subsequently treated with two courses of antibiotics, which resolved her symptoms.

A CT of the chest and the abdomen demonstrated moderate centrilobular emphysema with patchy peripheral consolidation in the right upper lobe, middle lobe and lingula, which was likely to be inflammatory in nature. Incidentally, it was found on CT scan that she had a duplication of her oesophagus and stomach (figures 1 and 2), with a

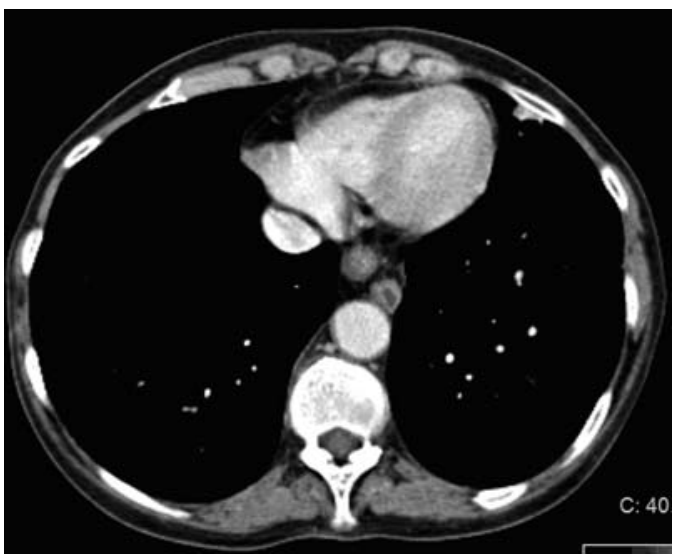

Figure 1 CT scan showing duplication of oesophagus.

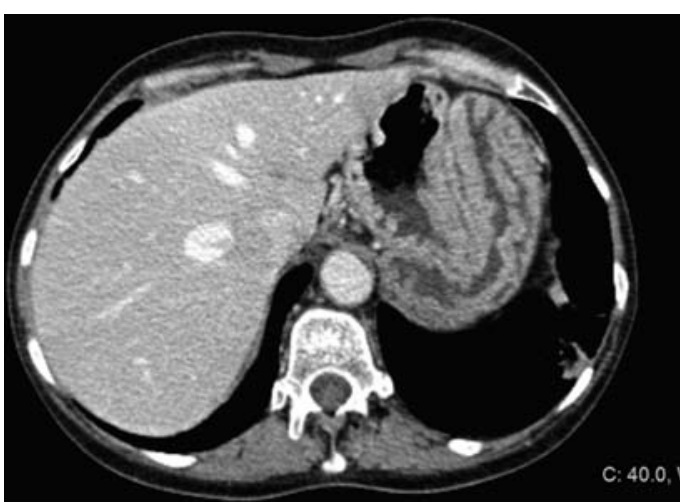

Figure 2 CT scan showing duplication of stomach.

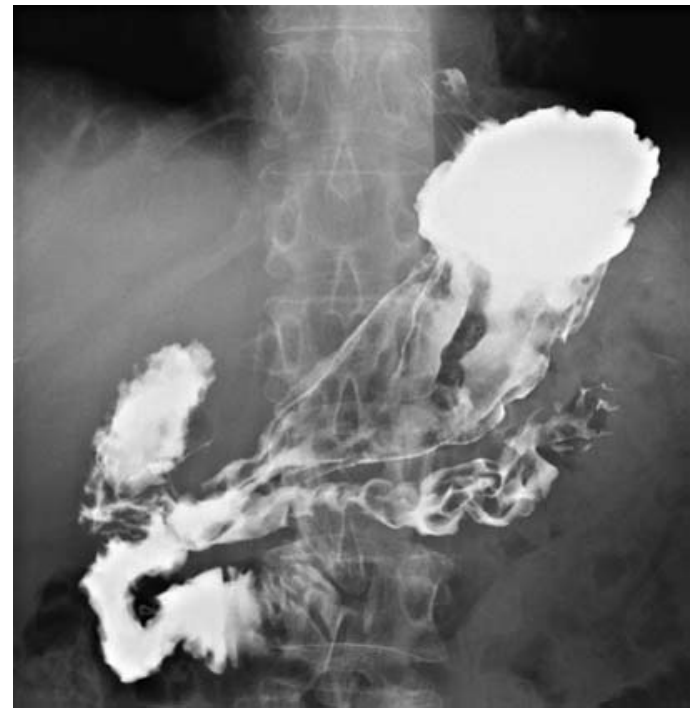

Figure 3 Barium swallow showing reflux disease and two stomachs connecting at the pylorus.

small hiatus hernia affecting one of the stomachs. Both stomachs had normal appearances and were connected at the pylorus. The level at which the duplication occurred in the oesophagus was not clearly demonstrated on CT scan. A barium swallow was arranged to demonstrate reflux and confirm duplication of the mid, distal oesophagus and stomach, connected at the level of the pylorus (figure 3). A trial of proton pump inhibitors improved her symptoms. Certainly, the dual oesophagus and stomachs could contribute to possible recurrent aspiration pneumoniae and chronic cough. She continues to be followed up in the respiratory clinic.

\section{Learning points}

- Always consider further imaging in a patient with chronic cough.

- If aspiration is a possibility, treat the underlying cause and think about proton pump inhibition.

Contributors AL wrote the case report under the supervision of $L B$ and PMCP. PMcP reported and edited the imaging.

Competing interests None declared.

Patient consent Obtained.

Provenance and peer review Not commissioned; externally peer reviewed. 


\section{Images in...}

Copyright 2015 BMJ Publishing Group. All rights reserved. For permission to reuse any of this content visit http://group.bmj.com/group/rights-licensing/permissions.

BMJ Case Report Fellows may re-use this article for personal use and teaching without any further permission.

Become a Fellow of BMJ Case Reports today and you can:

- Submit as many cases as you like

- Enjoy fast sympathetic peer review and rapid publication of accepted articles

- Access all the published articles

- Re-use any of the published material for personal use and teaching without further permission

For information on Institutional Fellowships contact consortiasales@bmjgroup.com

Visit casereports.bmj.com for more articles like this and to become a Fellow 